\title{
【特 集：廃棄物・環境亡会計】
}

\section{CSR 会計の体系}

\author{
國 部 克 彦*
}

【要 旨】 CSR（企業の社会的責任）は企業経営における重要な経営課題となっている。環境報告書 を社会事項にも拡張して CSR 報告書を作成・発行する企業す增加傾向にあり，CSR 会計にあ注目が集 まっている。しかし，CSR 会計は経済活動組織である企業とCSR 活動を連携する会計であるが，まだ 標準化されているわけではない。本稿では，CSR 会計が備えるべき条件をGRI「サステナビリティ・ レポーティング・ガイドライン」（G 3) から導出し，そのための会計計算書をCSR 活動の結果を示す 会計と，CSR 活動の手段としての会計に体系化すべきことを主張する。

キーワード：CSR 会計，GRI，付加価値計算書，環境会計

\section{1.はじめに}

21 世紀に入ってから， 企業の社会的責任（corporate social responsibility : CSR) を求める声は強まってい る。過去にも企業に社会的責任を問う声が強まった時代 はあったあのの†, それらはいずれあ一時的な現象で あったのに対して, 現在の CSR 重視の傾向は, 経済活 動にしっかりとビルインされた持続的な特徴として理解 すべきである。

その理由のひとつは, 現在の CSR を求める動きが, EU の政策に端を発していることがあげられる。EUで は, 2000 年にリスボン戦略を策定したことを契機とし て, 企業の社会的責任をひとつの政策的課題として追求 してきた。EUが規定するCSR とは，企業の自主的な 活動であり法的義務を超えたものであるが, 企業の自主 的な CSR 活動を促す制度的な基盤作りが進行してい る1)。

このようなヨーロッパの動向を受けて，アメリカや日 本さらにはアジアでも企業の社会的責任が重視される傾 向が強まっている。CSR の中心的な課題は, 環境問題 と社会問題であり, その相対的なウェートは地域や業種

原稿受付 2007.5.18

* 神戸大学大学院経営学研究科 教授

連絡先：６57-8501 神戸市溗区六甲台町 2-1

E-mail : kokubu@kobe-u.ac.jp
によって異なるが, 環境と社会をひとつの領域として CSR という概念で包括的に理解されるようになってき ている。企業でむ，これまで環境報告書として発行して きた自主的なレポートを, 社会環境報告書, CSR 報告 書, サステナビリティ報告書碑な゙の名称で刊行するよ うになってきたのは,このような状況を反映している。 CSR が企業活動にとって重要な側面であるならば, その結果を, どのようにステイクホルダーに伝達するか あ非常に重要な課題となる。その方法はいくつ考えられ るが，企業が経済活動を行う組織体であることを考慮す れば，CSRに関係する経済情報はその最む本質的な情 報となる可能性がある。

企業経営内部において環境と経済の関係領域を環境会 計と総括することができるように, CSR と経済の関係 領域もCSR 会計と呼ぶことができる。実際に, 「CSR 会計」あるいは「サステナビリティ会計」という呼称が

†たとえば, 1970 年代半ばには公害問題が深刻化したことに よって企業責任の追求が強まったし, 経済状態が好調だった 1980 年代末から 1990 年代にかけて企業の社会的貢献（フィラ ンソロピー）が強調された。

"「サステナビリティ」という用語の定義はいろいろあるが, CSR の世界では， サステナビリティは経済・環境・社会の 3 つ の側面の調和の取れた発展（トリプルボトムライン）を意味す る場合が多いので, 本稿でもこの定義に従うことにする。これ は, GRIによる「サステナビリティ・レポーティング・ガイド ライン」と同様のものである。 
提唱され, 麗澤大学企業倫理センター2)やイギリスの SIGMA ガイドライン ${ }^{\dagger 3}$ ではCSR 会計（あるいはサス テナビリティ会計）の体系が示されている。また，いく つかの企業ではこのような名称の会計計算書を CSR 報 告書上で開示している。

しかしながら, 現状のCSR 会計は, 会計という名称が 付けられるほどには，体系化・標準化されているという ことはできない。麗澤大学企業倫理センターも SIGMA ガイドラインも企業実践に根ざした体系化というよりも 理論先行の体系であり ${ }^{4)}$, 一方の企業実務は CSR 会計 をシステム的に実行するレベルまで発展しておらず，両 者の間の落差は大きい。これは, 会計としての体系化を 論じる前に, CSR 情報としてどのような経済情報が必 要なのか, それらの経済情報は相互にどのような関係に あるのかという基本的な事項について，まだ合意が成立 していないことに大きな原因があると考えられる。

そこで本稿では，CSR 会計をめぐるこのような状況 を鑑み，CSRに関する経済情報として要求される事項 を整理し，それらをCSR 会計として体系化するための 方向性を検討することを目的とする。そのためには, CSR に関する経済情報の考察から開始する必要がある ため，世界的な CSR 報告書の基準として活用されてい る GRI (Global Reporting Initiative) の「サステナビ リティ・レポーティング・ガイドライン第 3 版」5)（通 称 G $3 ： 2006$ 年発行）を基礎として分析を開始するこ とにしたい。

\section{GRI・G 3 が求める経済情報}

GRI は, 企業が作成する環境報告書について, 国際 的に基準とすべきガイドラインを作成することを目的に 結成された国際的な民間組織で, 2000 年に「サステナ ビリティ・レポーティング・ガイドライン」を発表した。 GRI は当初環境報告書の作成基準作成を目指していた が、J. エルキントン闪提唱する経済・社会・環境の 3 つの調和のとれた発展を目指す「トリプルボトムライ ン」の概念を採用したことによって, 環境報告書だけで はなく, 社会や経済の領域を加えたサステナビリティ報 告書のガイドラインとしての特徴を持つこととなった。 GRI は 2000 年に発行したガイドラインを 2002 年に

† SIGMA ガイドラインは, イギリス貿易産業省の支援のもと で, イギリス規格協会, アカウンタビリティ, フォーラム フォーザフューチャーの 3 つ組織が協力して作成し, 2003 年に 完成したサステナビリティ経営のためのガイドラインであり, 原則と 13 のッールキットから構成される。
改訂し, 2006 年には再度改訂して第 3 版を G 3 として 公表した。2006 年の改訂は 2002 年以降の企業の環境や 社会に関する動向を反映させた大規模なもので，G 3 は 「レポーティングガイドライン」と「指標プロトコル」 の 2 つからなる体系的な報告原則へと発展した。「指 標プロトコル」は, 経済 (EC), 環境 (EN), 製品責任 (PR), 労㗢関係とディーセントワーク（公正かつ誠実 な労働環境) (IP), 人権 (HR), 社会 (SO) の6つから 構成され, 経済指標はその中心のひとつとして位置づけ られている。

G 3 では, サステナビリティ報告書に求められる経済 情報に関して,「サステナビリティの経済的側面は, そ のステイクホルダーの経済状況および地域, 国, グロー バルなレベルの経済システム，に対して組織が及ぼす影 響に関連するもの」と述べ，(1)異なるステイクホルダー 間の価値の流れ゙，(2)社会における組織の主な経済影響, の 2 つを中心している。

そして, 実際に開示が奖励される経済パフォーマンス 指標は, (1)経済的パフォーマンス, (2)市場でのプレゼン ス, (3)間接的な経済影響, の3つに分けられることにな る。なお, 企業は財務報告書において多くの経済情報を 提供しているがそれらの多くは株主・投資家の関心事に 集中しており，サステナビリティ報告書が求める経済情 報は, 多様なステイクホルダーの関心事を対象とするす のである。

GRIでは，指標のランクを中核指標と追加指標に分 けており, 上記の 3 つの経済パフォーマンス指標の分野 での指標は以下のとおりである。

(1) 経斉的パフォーマンス

EC 1 (中核)：収益, 事業コスト, 従業員の給与, 寄付およびその他のコミュニティへの投資, 内部 留保および資本提供者や政府に対する支払いなど， 創出したおよび分配した直接的な経済価値

EC 2 (中核)：気候変動による, 組織の活動に対す る財務上の影響およびその他のリスクと機会

EC 3 (中核)：確定給付（福利厚生）制度の組織負 担の範囲

$\mathrm{EC} 4$ (中核)：政府から受けた相当の財務的支援

(2) 市場でのプレゼンス

EC 5 (追加)：主要事業拠点について，現地の最低 貨金と比較した標準的新入社員后金の比率の幅

\# G 3 を直訳すると「資本の流れ」になるが，内容的には「価 值の流れ」を示しているので, 訳語としても「価值の流れ」を あてることとする。 
EC 6 (中核)：主要事業拠点での地元サプライヤー （供給者）についての方針，業務刊行および支出 の割合

EC 7 (中核)：現地採用の手順，主要事業拠点で現 地コミュニティから上級管理職となった従業員の 割合

\section{(3) 間接的な経済影響}

EC 8 (中核)：商業活動，現物支給，または無料奉 仕を通じて主に公共の利益のために提供されるイ ンフラ投資およびサービスの展開図と影響

EC 9 (追加）：影響の程度など，著しい間接的な経 済的影響の把握と記述

GRI によれば，これらの指標は，(1)異なるステイク ホルダー間の価値の流れ，(2)社会における組織の主な経 済影響，を記述するための指標とされており，これは GRI が考える CSR 会計の目的と理解しても間違いでな い。会計学的にこの 2 つを区別するならば，(1)は企業が 獲得した価値を配分する側面であり，(2)は会計で捕捉さ れない側面も含めた企業の社会的影響に関する側面であ る。これを CSR 会計への要求事項と考えれば，どのよ うな会計システムを考案することができるであろうか。 この点について節を改めて検討しよう。

\section{3．異なるステイクホルダー間の価値の流れ}

企業は経済的組織であるから，企業による経済的な 資源の配分は，社会に対して影響を与えることになる。 企業による資源の配分には，獲得した価値を関係する ステイクホルダーに配分する側面が重要で， G 3 では, EC1によって果たされることになる。

EC 1 では表 1 のような計算書のフォーマットを示し て, 企業が獲得した経済価値の配分状況を開示すること を奨励している。

表 1 は, 売上高として獲得された直接的経済的価値を,
事業コスト, 従業員, 資本提供者, 政府, コミュニティ へいかに配分したかを示すあのである。このような計算 書はこれまで付加価値計算書として理解されてきた計算 書と類似のものであるが， G 3 が示す計算書では付加価 值ではなく，売上高を起点として，事業コストも企業価 値の配分原資と考えている。

一方，付加価値会計の理論によれば，付加価值とは売 上高から原材料・仕入高などの前給付費用を控除したも のであり, 付加価値を, 従業員, 資本提供者, 政府機関 などの主要ステイクホルダーによ゙のように配分されたの かが問題となる。会計理論的に考えれば，G 3でいうと ころの事業コストは売上高を生み出すために投下された あのであり，創出した経斉価値の配分項目ではない。

したがって, 企業が獲得した価値のステイクホルダー への配分状況を示す計算書としては，G 3 が提案する フォーマットよりも付加価値計算書の方が理論的である。 表 1 の収益(a) から事業コスト（b）を控除して付加価 值として示せば，付加価値計算書に変換できる。しかし ながら，G 3 が表 1 の形式を選択した理由は，事業コス トの受取手であるサプライヤーなども含めて価値の流れ を把握することを重視したためと推察できる。

G 3 の表 1 で示されているような内容は，通常の損益 計算書でも把握されている事項ばかりである。しかし， 損益計算書と表 1 はその目的とするところが異なる。損 益計算書では, 株主への利益が唯一のボトムラインとし て，それ以外の項目は費用であるのに対して，表 1 では， 株主への配分も企業価値の流れのひとつと位置づけられ るのである。このような企業価値の配分状況を示すこと で，企業によるステイクホルダー間の価値配分について の妥当性が示されることになる。

G 3 の EC 1 は付加価値額の算出は要求していないも のの, 内容的には付加価値計算書を再定式化したものと 理解することができる。付加価値計算書は, 日本ではあ まり歴史がないが，ヨーロッパでは労使交渉の手段とし て活用されてきた長い経緯がある778)。したがって, 企

表 1 GRI における創出した経済価値の分配表

\begin{tabular}{|c|c|}
\hline 構成要素 & 内 \\
\hline \multicolumn{2}{|l|}{ 創出した経済価值 } \\
\hline a ）収益 & 純売上高プラス金融投資・資産売却からの収入 \\
\hline \multicolumn{2}{|l|}{ 分配した経済価値 } \\
\hline b) 事業コスト & 仕入先への支払い，非戦略的投資，特許権の使用料，業務遂行費 \\
\hline c ）従業員給与と福利厚生 & 従業員に対する金銭的総支出（将来の支出ではなく, 現在の支出） \\
\hline d）資本提供者への支払い & 組織資本の提供者に対するすべての財務的支払い \\
\hline e ）政府への支払い（国ごと） & 総納税額 \\
\hline f) コミュニティ投資 & 広義のコミュニティに対する自発的貢献と投資（寄付を含む） \\
\hline $\begin{array}{l}\text { 留保された経済価値 } \\
\text { (創出された経済価値から分配した経済価値を控除したもの) }\end{array}$ & 投資，株式配当等 \\
\hline
\end{tabular}


業価値の配分計算書を CSR 会計のひとつの中心にすえ ることは,このような伝統を反映するものでああり, 妥 当なむのと考えられる。日本企業でも, 付加価値計算書 はじめ, 企業価値の配分計算書を CSR 報告書で開示す るケースもみられるようになってきている。

\section{4．社会における組織の主な経済影箁}

異なるステイクホルダーへの企業価値の配分に関して は, 表 1 のように計算書にまとめることが可能であるが, 企業が社会に与える経済的影響に関してはG 3 では計算 書類として提案するレベルには至っていない。「市場で のプレゼンス」や「間接的な経済的影響」に関する指標 がこの目的に適合すると考えられるが，それらの指標で 必要十分かは議論が分かれるであろうし, 計算書として 体系化されているわけですない。

これは GRI が理想的な計算書を指向するものでは なく, 現状の企業実務にあわせて, 可能な指標を選択 しているためである。これに対して SIGMA ガイドライ ンでは,「環境外部性評価報告書」と呼ぶべき環境会計 を提唱している。そこでは, 企業が環境に与えた外部不 経済をサステナビリティコストとして測定し, 企業利益 からサステナビリティコストをを控除した環境サステナ ビリティ調整利益を算出することを要求している9 。 SIGMA ガイドラインでは，環境への外部性だけでなく， 社会面への外部性を考虑した計算書も, 同ガイドライン が考えるサステナビリティ会計の体系に中に含めている が,これは雛形を示す段階にはなく, 部分的な企業事例 を記述的に説明するにとどまっている。

企業が環境や社会に与える外部性を測定しようとする 試みは, さまざまな機関が実施している。特に, 環境に 関しては, 多くの研究が蓄積され, その一部は実際に活 用されて, SIGMA ガイドラインの事例のように環境会 計に応用されている。しかし, 環境事項のみならず, 社 会事項まで拡張すると, 企業の外部性を測定する方法は はるかに困難となり, 現時点では非常に部分的な影響し か評価できず, 会計としてシステム化できる段階ではな い。

しかし、ここで重要なことは, 社会における組織の主 な経済影響を捕捉する方法の妥当性を検証することでは

†サステナビリティコストとは, 企業が, 現在の地球環境を維 持するために許容された範囲を超えて排出した環境負荷の量に その単位あたりの回避コストもしくは削減コストを乗じること によって算出されるもので, 企業が支出すべきであった（が支 出されなかった）環境保全コストを意味する。
なく, CSR 会計として, サステナビリティに関する経 済情報を開示していくにあたって,この領域が重要であ るというコンセンサスの存在である。G 3ではこの問題 について個別的事項の開示を求めるにとどまっているが, 将来的に CSR 会計として展開していくためには, 企業 の社会的影響の測定・開示が重要な論点となることを示 している。

\section{CSR 活動のコスト計算書}

GRI ガイドラインにおける経済指標は企業活動の結 果を示すすのである。しかし, 会計には結果を出すため の手段に関する領域むある。

たとえば，環境省の環境会計ガイドライン ${ }^{10)}$ は, 環境 保全のためのコストとその効果（環境保全効果と経済効 果）を対比するものであるが, 理論的には,これは環境 保全活動の効率性を示す計算書であって, 環境保全活動 の効果を示すすのではない。（ただし，環境保全コスト の負担というアカウンタビリティを示す目的はある。）

環境省ガイドライン型環境会計をCSR 活動にまで 拡張すると, CSR のコスト計算書が出来上がる。麗澤 大学企業倫理センターの「CSR 会計ガイドライン」で は「CSR 活動計算書」として, 主要な CSR 活動ごとの コストをまとめた計算書が示されている。SIGMA ガイ ドラインでも「社会財務計算書」として CSR 活動のた めのコストと，それによる収入もしくは費用節約額を対 比させた計算書が提案されている。

G 3 ではこのような CSR 活動のコスト計算書は開示 要求事項としては示されていないが, 環境保全コストを はじめとして, 主要な支出項目はそれぞれの CSR 活動 指標の中には含まれている。

日本でも，このような CSR 活動に関するコスト計算 書を開示している企業がみられる。これは，日本企業に とっては, 環境省環境会計ガイドラインの CSR 活動版 なので馴染みが深く, 環境会計の拡張版として作成する ことができるメリットがある11)。

\section{CSR 会計の体系化の視点 : むすびにかえて}

G 3 では，サステナビリティ報告書における経済情報 開示の目的として，(1)異なるステイクホルダー間の価値

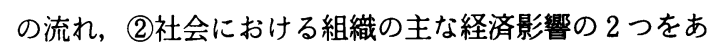

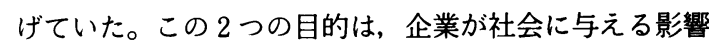
を企業内部と企業外部に分けて開示することを要求する あので, CSR 会計として合理的な目的であると考えら れる。 
表 2 CSR 会計の手段と結果の体系

\begin{tabular}{|c|c|}
\hline 手段としての会計 & 結果を示す会計 \\
\hline 生産性向上のための管理会計手法 & $\begin{array}{l}\text { 異なるステイクホルダー間の価値の流れを示す計算書 } \\
\text { ex. 付加価値計算書 }\end{array}$ \\
\hline $\begin{array}{l}\text { 環境や社会活動に関するコスト・効果を示す計算書 } \\
\text { ex. 環親筫環境会計 }\end{array}$ & $\begin{array}{l}\text { 社会における組織の主な経済影響を示す計算書 } \\
\text { ex. SIGMA 環境外部性評価計算書 }\end{array}$ \\
\hline
\end{tabular}

G 3 では11関しては創出した経済価値の配分計算書 を掲示しているが，(2)関しては体系的な計算書を示す ことはしておらず, 個別的な経済指標を列挙するにとど まっている。これは,このような企業が外部経済に与え る影響を測定することの困難さに起因している。しかし， SIGMA ガイドラインでは, 環境面に関しては, 環境外 部性を評価する計算書を提案しており，これを社会面に まで拡張することは今後の研究課題となっている。

一方, 日本での環境省環境会計ガイドラインに典型的 に見られるように, 環境保全活動（もしくはCSR 活 動）に投下したコストとその効果を対比する会計も実務 的には広く普及している。しかしながら，このようなコ ストと効果の対比を中心とする会計は, 環境保全活動や CSR 活動の効率性は示すことはできても，CSR 活動の 結果を開示する計算書ではないことに注意すべきであ $3^{12)}$ 。

環境会計を含むCSR 会計の領域では，さまざまな会 計計算書が提案されたり, 実務で利用されたりしている ため, 目的と手段の関係という会計学における基本の体 系が看過されやすい。本稿で議論してきたことに基づけ ば, CSR 会計は, (1)異なるステイクホルダー間の価値 の流れ，(2)社会における組織の主な経済影響，という2 つの結果を示す計算書と, それらの結果をもたらすため の手段としての会計に体系化されるべきである。

この関係を図示すると, 表 2 のように書くことができ

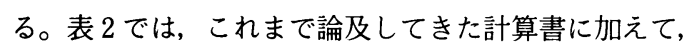
異なるステイクホルダー間の価値の流れを示す計算の手 段として生産性向上のための管理会計手法をあげている。 この部分は GRI などで言及されているわけではないが, 本稿での考察から理論的に導出したものであり, 生産性 向上のための管理会計とは企業のインプットとアウト プットの効率性向上を目指すッールであり, 従業員への 配分額む含めた付加価值向上を目的とする手段一般を指 す。

表 2 で示した CSR 会計の体系は, 現状の実務および 理論から導出したものであり, 改善の余地は残されてい る。何よりも, 社会が企業に対して要求する経済情報が 変化すれば, 当然開示すべき内容も変わるからである。 しかし, 会計計算書には, 結果を示す計算書と, 結果を
出すための手段としての計算書があり，この両者を混同 しては有効な体系化を図ることは難しい。本稿では，G 3 が求める CSR に関する経済情報をCSR 会計の結果 を示す会計として展開することが可能であることを示す と同時に, 企業実務として普及しているCSR 活動のコ ストを中心に計算する会計はそのための手段として位置 づけられることを示した。

ただ，本稿での考察は理論的な関係性を整理したに過 ぎず，手段と結果の具体的な関係性の確立は個別の実践 の中で達成されるべき課題である。

\section{[謝 辞]}

本稿は, 科学研究費補助金基盤研究 (C) (課題 番号 18530348）の研究成果の一部である。

\section{考文献}

1) EC: Communication From the Commission Concerning Corporate Social Responsibility, EC (2002)

2) 麗澤大学企業倫理研究センター：CSR 会計ガイドラ イン（R-BEC 004）, 麗澤大学企業倫理研究センター (2004)

3) SIGMA: The SIGMA Guidelines, SIGMA (2003) (BSI ジャパン訳：SIGMA ガイドライン, BSI ジャパ ン (2004))

4) 國部克彦: サステナビリティ会計の体系, 神戸大学大 学院経営学研究科ディスカッションペーパー (2005)

5) GRI: Sustainability Reporting Guidelines, GRI (2006)（GRI 日本フォーラム訳：サステナビリティ レポーティングガイドラィン, GRI 日本フォーラム (2006))

6) J. Elkington: Cannibals with Forks: The Triple Bottom Line of $21^{\text {st }}$ Century Business, Capstone (1997)

7 ）山上達人：付加価値会計の研究, 有斐閣（1984）

8 ) 向山敦夫：社会環境会計論, 白桃書房（2003）

9 ) 國部克彦: 環境会計と企業経営評価, 経営分析研究, 第 22 号, pp. 50-57 (2006)

10）環境省：環境会計ガイドライン，環境省（2005）

11）國部克彦, 伊坪徳宏, 水口 剛: 環境経営 - 会計, 有斐 閣 (2007)

12）國部克彦：環境会計体系再考, 會計, 第 168 巻, 第 6 号, pp. 13-23 (2005) 


\title{
The System of CSR Accounting
}

\author{
Katsuhiko Kokubu \\ Kobe University, Graduate School of Business Administration \\ ( 2-1 Rokkodai, Nada-ku, Kobe 657-8501 Japan)
}

\begin{abstract}
CSR has become important for business management. The number of companies that revise their environmental report to CSR report, by adding information on their social affairs, is increasing. Although CSR accounting has been attracting significant interest from business communities, it has not yet been standardized. This paper analyzes GRI Sustainability Reporting Guidelines (G 3 ) regarding economic indicators on CSR, and proposes a system of CSR accounting by which it is divided into accounting for results and accounting for means.
\end{abstract}

Key words : CSR accounting, GRI, value added statement, environmental accounting 